\title{
PEMAKAIAN MOBILE ROBOT DALAM MENINGKATKAN PERKEMBANGAN KOGNITIF ANAK USIA DINI DI TAMAN KANAK-KANAK
}

\author{
Anip Febtriko \\ Teknik Informatika, Fakultas Teknik, Universitas Abdurrab \\ Jl. Riau Ujung No. 73 Pekanbaru Riau Indonesia \\ E-Mail : aniep.febtric@gmail.com
}

\begin{abstract}
ABSTRAK
Kognitif diartikan potensi intelektual yang terdiri dari tahapan pengetahuan,pemahaman, penerapan, analisa ,sintesa, evaluasi. Kognitif berarti persoalan yang menyangkut kemampuan untuk mengembangkan kemampuan rasional (akal). Penelitian ini bertujuan untuk mengetahui peningkatan perkembangan kognitif anak dalam mengenal bentuk setelah diterapkan metode bermain Mobile Robot pada taman kanak-kanak . Jenis penelitian ini adalah penelitian tindakan kelas yang dilaksanakan dalam dua siklus. Populasi dalam pengambilan sampel berjumlah 20 orang anak. Data penelitian tentang perkembangan kognitif dalam mengenal bentuk dan kreatifitas dikumpulkan dengan metode observasi. Data hasil penelitian dianalisis dengan menggunakan metode analisis statistik deskriptif dan metode analisis deskriptif kuantitatif. Hasil analisis data menunjukkan bahwa terjadi peningkatan perkembangan kognitif dalam mengenal bentuk dan kreatifitas setelah penerapan metode bermain Mobile Robot Salah satu cara untuk meningkatkan kreatifitas pada anak di taman kanak-kanak adalah dengan terapi bermain mobile robot. Media mobile robot adalah suatu aktivitas mengendalikan dan mengatur pergerakan dari robot tersebut yang melibatkan dan membutuhkan koordinasi antara mata, tangan, dan konsentrasi. Sangat perlu adanya pendekatan dan penggunaan mobile robot dalam efektifitas peningkatan kognitif pada anak. Mobile robot sebagai media yang menjadi alat terapi bermain dengan kemampuan mobile robot yang bisa bergerak dan berpindah dari satu tempat ke tempat yang lain dengan mengikuti pola garis yang telah dirancang. Tujuan utama dari penelitian ini adalah merancang kreatifitas sesuai dengan tingkat kompleksitas penggunakan mobile robot untuk anak-anak. Disamping penggunaan mobile robot sebagai media terapi bermain juga ada analisa dalam penelitian menggunakan desain Pre eksperimen. Pengumpulan data untuk mengkaji kognitif pada anak, data yang terkumpul dianalisa dengan analisa deskritif dan uji Rank Wilcoxon.
\end{abstract}

Kata kunci : Kognitif, Mobile Robot

\begin{abstract}
Cognitive interpreted the intellectual potential consisting of stages of knowledge, understanding, application, analysis, synthesis, evaluation. Cognitive means issues involving the ability to develop rational skills (reason). This study aims to determine the improvement of cognitive development of children in recognizing the form after applied method of playing Mobile Robot in kindergarten. This type of research is a classroom action research conducted in two cycles. Population in the sampling amounted to 20 children. Research data on cognitive development in recognizing form and creativity collected by observation method. The data of the research were analyzed by using descriptive statistic analysis method and quantitative descriptive analysis method. The results of data analysis show that there is an increase in cognitive development in recognizing the form and creativity after the application of the method of playing Mobile Robot One way to increase creativity in children in kindergarten is by playing mobile robot therapy. Mobile robot media is an activity to control and regulate the movement of the robot that involves and requires coordination between the eyes, hands, and concentration. It is necessary to approach and use mobile robot in the effectiveness of cognitive improvement in children. Mobile robot as a medium that becomes a play therapy device with mobile robot capability that can move and move from one place to another by following the pattern of lines that have been designed. The main purpose of this research is to design creativity according to the level of complexity of mobile robot use for children. In addition to the use of mobile robot as a medium of play therapy there is also analysis in research using Pre experimental design. Data collection to assess cognitive in children, collected data were analyzed by descriptive analysis and Rank Wilcoxon test.
\end{abstract}

Keywords : cognitive, mobile robot 


\section{PENDAHULUAN}

Upaya untuk meningkatkan sumber daya manusia yang berkualitas. Untuk meningkatkan kualitas pendidikan, salah satu upaya yang dilakukan adalah menyelenggarakan pendidikan melalui jenjang pendidikan yang paling dasar yaitu Pendidikan Anak Usia Dini (PAUD), yang merupakan pondasi atau dasar dari jenjang pendidikan selanjutnya.

Sehubungan dengan perkembangan kognitif, kondisi persentase hasil belajar yang masih sangat rendah ini disebabkan oleh penggunaan cara-cara konvensional dalam pembelajaran anak, seperti kecenderungan guru menggunakan metode ceramah, dan kurangnya inovasi dalam pembelajaran di taman kanak-kanak serta masih kurangnya keberadaan media yang mampu menunjang motivasi anak mengikuti pembelajaran. Walaupun kegiatan

pembelajaran sudah dijelaskan oleh guru tetapi banyak anak yang kurang aktif dan kurang berkonsentrasi dalam mengikuti kegiatan pembelajaran

Media bermain untuk anak dengan penggunaan mobile robot, dengan adanya mobile robot dapat melakukan interaksi pergerakan saat bermain melibatkan bagianbagian tubuh tertentu dan diawali oleh perkembangan otot-otot kecil seperti keterampilan menggunakkan jari-jemari tangan dan gerakan pergerakan tangan yang luwes, melatih koordinasi mata anak. Salah satu pencapaian perkembangan terdapat kemampuan mengendalikan mobile robot dengan mengikuti pola jalur robot berupa garis lurus, melengkung, lingkaran, segi empat, segi tiga dan pola yang lainnya.

\section{Rumusan Masalah}

1. Apakah mobile robot dapat memberikan peningkatan kognitif pada taman kanak-kanak?

2. Bagaimana hasil perbedaan analisa sebelum dan sesudah dari penggunaan mobile robot dengan uji Wilcoxon?

\section{Batasan Masalah}

Agar penelitian ini terarah, maka perlu ada batasan masalah sebagai berikut :

1. Bentuk mobile robot yang digunakan dalam meningkatkan kognitig berupa robot yang mengikuti bermacam pola garis.

2. Analisa dalam penelitian ini menggunakan uji wilcoxon untuk mengetahui hasil kognitif pada anak.

\section{Tujuan}

1. Mengetahui efektifitas penggunaan mobile robot terhadap kognitif anak.

2. Mengetahui hasil analisa perbandingan sebelum dan sesudah dari pengguanaan mobile robot dengan menggunakan Rank Wilcoxon.

\section{Pengertian Pengukuran Perkembangan Kognitif Peserta Didik}

Pengukuran (measurement) adalah proses pemberian angka atau usaha memperoleh deskripsi numerik dari suatu tingkatan di mana seorang peserta didik telah mencapai karakteristik tertentu. Pengukuran adalah penentuan besaran, dimensi, atau kapasitas, biasanya terhadap suatu standar atau satuan pengukuran. Pengukuran tidak hanya terbatas pada kuantitas fisik, tetapi juga dapat diperluas untuk mengukur hampir semua benda yang bisa dibayangkan, seperti tingkat ketidakpastian, atau kepercayaan 
konsumen. Sedangkan perkembangan kognitif adalah pengetahuan atau yang mencakup kecerdasan bahasa dan kecerdasan logika - matematika.

\section{Konsep Dasar Pengukuran Perkembangan Kognitif Pendidikan Anak Usia Dini}

Pengukuran pendidikan prasekolah (usia dini) dapat diartikan sebagai proses penilaian tentang kedudukan program pendidikan prasekolah (usia dini) yang dilaksanakan. Sedangkan secara lengkap batasan dari pengukuran pendidikan prasekolah (usia dini) dapat didefinisikan sebagai suatu upaya dan proses memilih, mengumpulkan, serta menafsirkan informasi tentang posisi program maupun anak, baik terkait dengan pertumbuhan, perkembangan, kemajuan, perubahan serta kemampuan yang menjangkau berbagai aspek (bidang pengembangan) melalui cara-cara yang benar, tepat, akurat, terencana dan sistematis pada dimensi proses maupun hasil, sehingga keputusan yang diambil sesuai dengan kriteria yang semestinya, yaitu tidak merugikan, sesuai tujuan dan nilai sebagaimana yang telah ditetapkan.

Pada evaluasi perkembangan anak usia dini, measurement lebih banyak digunakan dari pada evaluasi yang bersifat formal atau menggunakan tes standar. Hal ini karena pola perkembangan anak masih bersifat sederhana, dan mereka banyak menghabiskan waktu melalui kegiatan bermain bersama. Untuk dapat merekam dan mendeskripsikan perkembangan anak dengan tepat dibutuhkan suasana yang alami. Oleh karena itu, asesmen lebih tepat diterapkan untuk anak usia dini, dari pada evaluasi.

Proses evaluasi pada anak usia dini (AUD)/ TK, adalah pengamatan, pencatatan, dan pendokumentasian kinerja dan karya siswa serta bagaimana proses anak menhasilkan karya tersebut (Grace dan Shore, 1991; Kumano, 2002). Asesmen tidak digunakan untuk mengukur suatu keberhasilan suatu program tetapi untuk mengetahui perkembangan atau kemajuan belajar anak. Dalam aplikasinya di PAUD (Pendidikan Anak Usia Dini), asesmen tersebut tidak dilakukan di kelas pada akhir program atau akhir tahun tetapi dilakukan secara bertahap dan berkesinambungan. Dengan cara anak bermain, mengambar, atau dari karya yang dihasilkan. Dengan asesmen guru dapat mengetahui bakat, minat, kelebihan,dan kelemahan anak. Guru bersama orang tua siswa dapat memberi bantuan belajar yang tepat untuk anak sehingga dapat diperoleh hasil belajar yang optimal.

Pengukuran perkembangan kognitif pada anak usia dini meliputi:

1. Perkembangan fisik motorik

2. perkembangan kognitif/intelektual

3. perkembangan moral dan sosial

4. perkembangan sosio emosional

5. perkembangan bahasa dan seni.

Pengukuran kognitif anak usia dini digunakan untuk berbagai tujuan antara lain:

1. Untuk mengetahui berbagai aspek perkembangan anak secara individual.

2. Untuk diagnosa adanya hambatan perkembangan maupun identifikasi penyebab masalah belajar anak.

3. Untuk memberikan tempat dan program yang tepat bagi anak (apakah dibutuhkan program pelayanan khusus).

4. Untuk membuat perencanaan program (curriculum planning) dan memberikan umpan balik bagi anak. 
5. Untuk mengidentifikasi dan memperbaiki masalah perkembangan pada anak.

Dengan demikian kegiatan pengukuran yang dilakukan hendaknya disesuaikan dengan tujuan pengkuran yang hendak dicapai, agar mendapatkan hasil yang maksimal. Untuk melaksanakan kegiatan pengukuran dibutuhkan perencanaan yang baik, serta instrument (alat) yang tepat untuk mengukur perkembangan anak .

Dalam pelatihan ini difokuskan pada pengukuran perkembangan kognitif/intelektual yang meliputi:

1. tahap perkembangan kognitif anak usia dini.

2. indikator pencapaian tahap perkembangan kognitif.

3. penyusunan instrumen untuk asesmen perkembangan.

Pengajar harus mengetahui sejauh mana pembelajar (learner) telah mengerti bahan yang telah diajarkan atau sejauh mana tujuan/kompetensi dari kegiatan pembelajaran yang dikelola dapat dicapai. Tingkat pencapaian kompetensi atau tujuan instruksional dari kegiatan pembelajaran yang telah dilaksanakan itu dapat dinyatakan dengan nilai. Namun, dalam praxis pendidikan di Indonesia yang tercermin dalam proses belajar-mengajar dan penilaian, yang amat ditekankan justru perkembangan kognitif. Hal ini terutama direfleksikan dalam 4 kelompok mata pelajaran, yaitu bahasa, matematika, sains, dan ilmu-ilmu sosial. Domain psikomotor yang terutama direfleksikan dalam mata-mata pelajaran pendidikan jasmani, keterampilan, dan kesenian cenderung disepelekan.

Perubahan paradigma pendidikan dari behavioristik ke konstruktivistik tidak hanya menuntut adanya perubahan dalam proses pembelajaran, tetapi juga termasuk perubahan dalam melaksanakan penilaian pembelajaran siswa. Dalam paradigma lama, penilaian pembelajaran lebih ditekankan pada hasil (produk) dan cenderung hanya menilai kemampuan aspek kognitif, yang kadang-kadang direduksi sedemikian rupa melalui bentuk tes obyektif. Sementara, penilaian dalam aspek afektif dan psikomotorik kerapkali diabaikan.

Dalam pembelajaran berbasis konstruktivisme, pengukuran pembelajaran tidak hanya ditujukan untuk mengukur tingkat kemampuan kognitif semata, tetapi mencakup seluruh aspek kepribadian siswa, seperti: perkembangan moral, perkembangan emosional, perkembangan sosial dan aspekaspek kepribadian individu lainnya. Demikian pula, penilaian tidak hanya bertumpu pada penilaian produk, tetapi juga mempertimbangkan segi proses.

\section{Macam-Macam Skala Pengukuran}

Skala pengukuran merupakan seperangkat aturan yang diperlukan untuk mengkuantitatifkan data dari pengukuran suatu variable. Dalam melakukan analisis statistik, perbedaan jenis data sangat berpengaruh terhadap pemilihan model atau alat uji statistik. Tidak sembarangan jenis data dapat digunakan oleh alat uji tertentu.

1. Skala

Nominal

Pengukuran dengan skala nominal merupakan tingkat mengkategorikan, memberi nama dan menghitung fakta-fakta dari obyek yang diteliti. Dimana angka yang diberikan pada obyek hanya mempunyai arti sebagai label saja dan tidak menunjukkan kegiatan yang tidak berarti.

contoh, kita dapat menempatkan individu untuk kategori seperti laki-laki dan perempuan tergantung pada jenis kelamin 
mereka, atau kecerdasan dengan kategori tinggi dan rendah berdasarkan nilai intelijen.

2. Skala

Ordinal

Skala (ukuran) ordinal adalah skala yang merupakan tingkat ukuran kedua, yang berjenjang sesuatu yang menjadi 'lebih' atau 'kurang' dari yang lainnya. Ukuran ini digunakan untuk mengurutkan objek dari yang terendah hingga tertinggi dan sebaliknya yang berarti peneliti sudah melakukan pengukuran terhadap variable yang diteliti.

Contohnya adalah: A lebih besar atau lebih baik dari pada B, B lebih besar dari atau lebih baik dari daripada $\mathrm{C}$, dan seterusnya. Hubungan tersebut ditunjuk oleh simbol '>' yang berarti 'Lebih besar dari' mengacu pada atribut tertentu. Kita bisa melanjutkan dengan latihan sebelumnya untuk membuatnya lebih jelas. Perlu diingat bahwa hubungan antara kedua peringkat adalah tidak bisa di gambarkan secara rinci bahwa nilai $\mathrm{A}$ adalah dua kali lipat dari $\mathrm{B}$ atau A empat kali lipat dari $\mathrm{C}$.

$3 . \quad$ Skala

Interval

Merupakan tingkat pengukuran ke tiga, dimana pemberian angka pada set objek yang memilih sifat ordinal, ditambah dengan satu sifat yang lain, yakni memberikan nilai absolute pada data/ objek yang akan diukur. Ukuran rasio ini mempunyai nilai nol (0) absolute (tidak ada nilainya).

Contoh Interval adalah timbangan seperti skala Fahrenheit dan IQ

\section{Skala Rasio}

Merupakan tingkat pengukuran tertinggi, dimana ukuran ini mencakup semua persyaratan pada ketiga jenis ukuran sebelumnya, ditambah dengan satu sifat yang lain, yakni ukuran ini memberikan nilai absolute pada data/objek yang akan diukur. Ukuran rasio ini mempunyai nilai nol (0)

Contoh : penghasilan pegawai 0 (berarti pegawai itu tidak menerima uang sedikitpun).

Meskipun sejumlah skala yang ada dapat dibuat untuk mengukur atribut orang, benda, peristiwa, dan sebagainya, semua skala memiliki empat tipe dasar yaitu: Nominal, Ordinal, Interval dan Rasio.

Skala ini sebenarnya merupakan empat hirarki prosedur pengukuran, terendah dalam hirarki adalah skala nominal dan yang tertinggi adalah skala pengukuran ratio. Itulah sebabnya 'Tingkat pengukuran' ini telah digunakan oleh beberapa sarjana dalam pembuatan dan penggunaan skala pengukuran.

\section{Teknik Pengukuran}

Beragam teknik dapat dilakukan untuk mengumpulkan informasi tentang perkembangan dan pertumbuhan anak usia dini. Teknik mengumpulkan informasi tersebut pada prinsipnya adalah cara pengukuran kemajuan perkembangan dan pertumbuhan anak berdasarkan standar kompetensi dan kompetensi dasar yang harus dicapai. Penilaian kompetensi dasar dilakukan berdasarkan indikatorindikator pencapaian hasil belajar yang memuat berbagai aspek perkembangan. Indikatorindikator pada setiap kompetensi dasar merupakan acuan yang digunakan untuk melakukan penilaian menggunakan alat dan cara penilaian serta serangkaian prosedur.

Di bawah ini dipaparkan berbagai teknik (measurement) pengukuran yang dapat dipilih guru untuk melakukan proses measurement (pengukuran), antara lain: 
(1) Unjuk Kerja (Performance)

(2) hasi karya produk (product)

(3) penilaian sikap

(4) portofolio

(5) penugasan (project)

Aspek perkembangan kognitif yang akan diukur terkait erat dengan teknik penilaian dan instrumen yang akan digunakan. Perilaku (kompetensi) yang terkait dengan aspek kognitif antara lain:

(a) bertanya tentang alat/media

(b) berhitung angka

(c) mengenal beberapa huruf dan angka

(d) menggolongkan benda berdasarkan ukuran, bentuk dan warna

(e) memahami persamaan dan perbedaan beberapa hal

(f) membangun balok

(g) membaca, dll.

\section{Uji Wilcoxon}

Uji jenjang bertanda Wilcoxon yang diperkenalkan oleh Frank Wilcoxon dalam tahun 1945 merupakan penyempurnaan dari "Uji Tanda" yakni di samping memperhatikan tanda positif dan negatif, besarnya perbedaan juga diperhatikan. Uji ini digunakan untuk menguji kondisi (variabel) pada sampel yang berpasangan dengan skor data yang minimal berskala ordinal atau juga untuk penelitian dengan data sebelum dan sesudah (Marx, Backes, Meese, Lenhof, \& Keller, 2016).

\section{Mobile Robot}

Robot adalah perangkat mekanik yang dapat dikendalikan oleh perangkat lunak yang menggunakan sensor untuk memandu satu atau lebih efektor melalui gerakan terprogram dalam suatu ruang kerja dalam hal untuk manipulasi obyek fisik (Wilson, Faisal, Al-assadi, \& Iwan, 2012).
Berdasarkan alat yang digunakan untuk bergerak, mobile robot terbagi menjadi robot berlengan atau berkaki lengan atau kaki menyerupai manusia (android) ataupun hewan, robot beroda Wheeled Mobile Robot (WMR) (Larkin, Ivutin, Kotov, \& Yesikov, 2017). Kerja pengindra sensor ini dalam navigasi robot selalu memancarkan gelombang kirim dan gelombang terima kembali setelah gelombang tersebut dipantulkan oleh dinding/penghalang di sisi kiri, kanan atau depan robot (Gumus, Topaloglu, \& Ozcelik, 2016). Contoh lainnya yang akan dibahas adalah mobile robot untuk melakukan maze solving. Berikut adalah gambar diagram blok system:

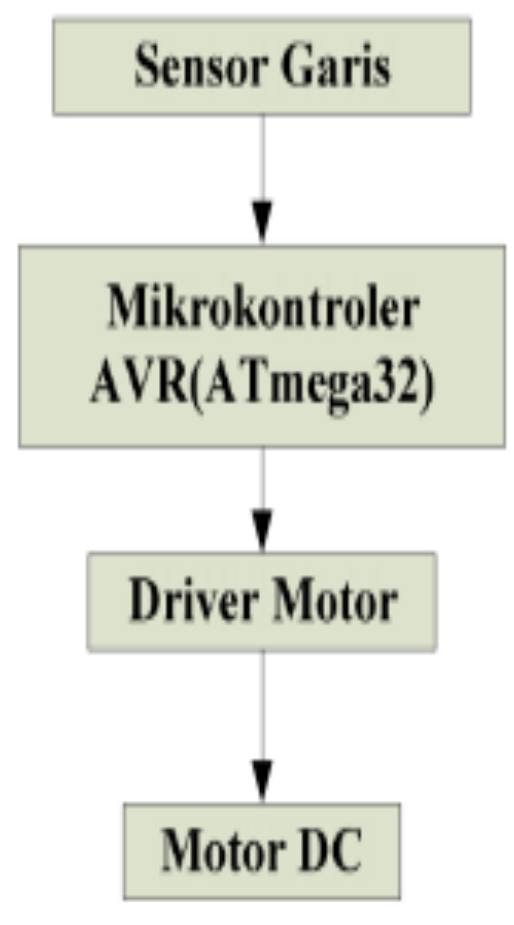

Gambar 1. Diagram blok system 


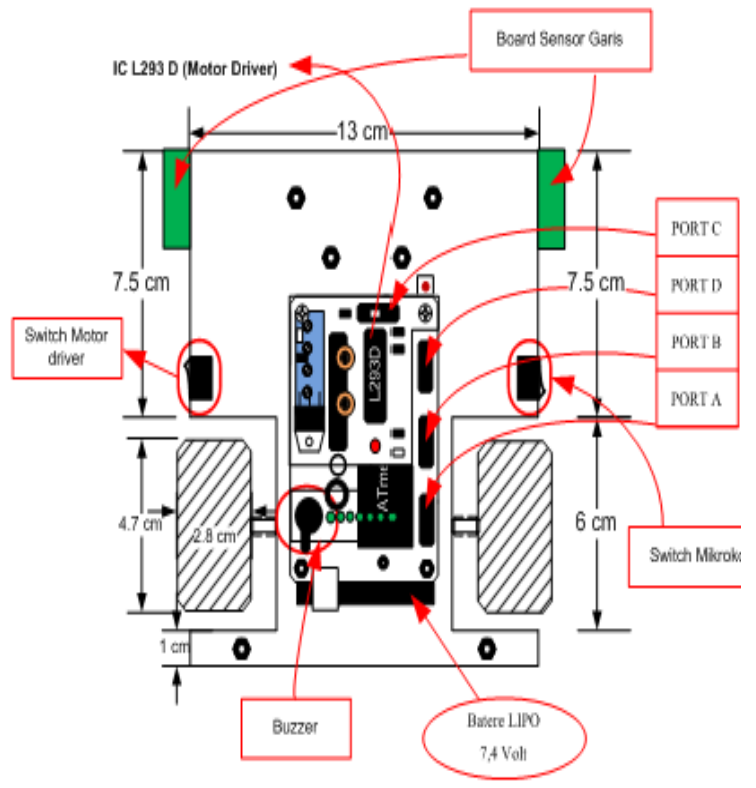

(a)

Gambar 2. Robot tampak atac

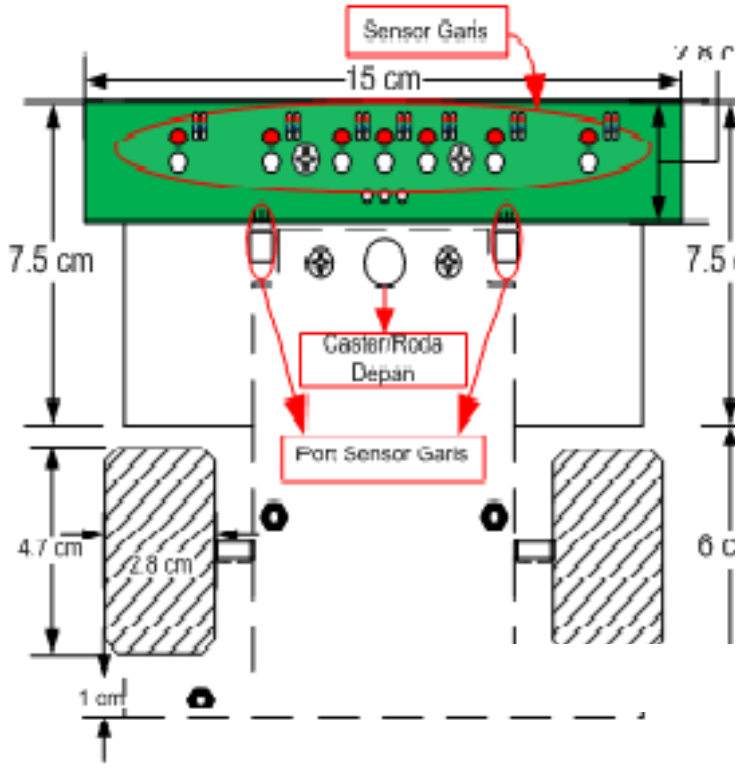

(b)

Gambar 3. Robot tampak
METODE

Kerang Kerja Penelitian

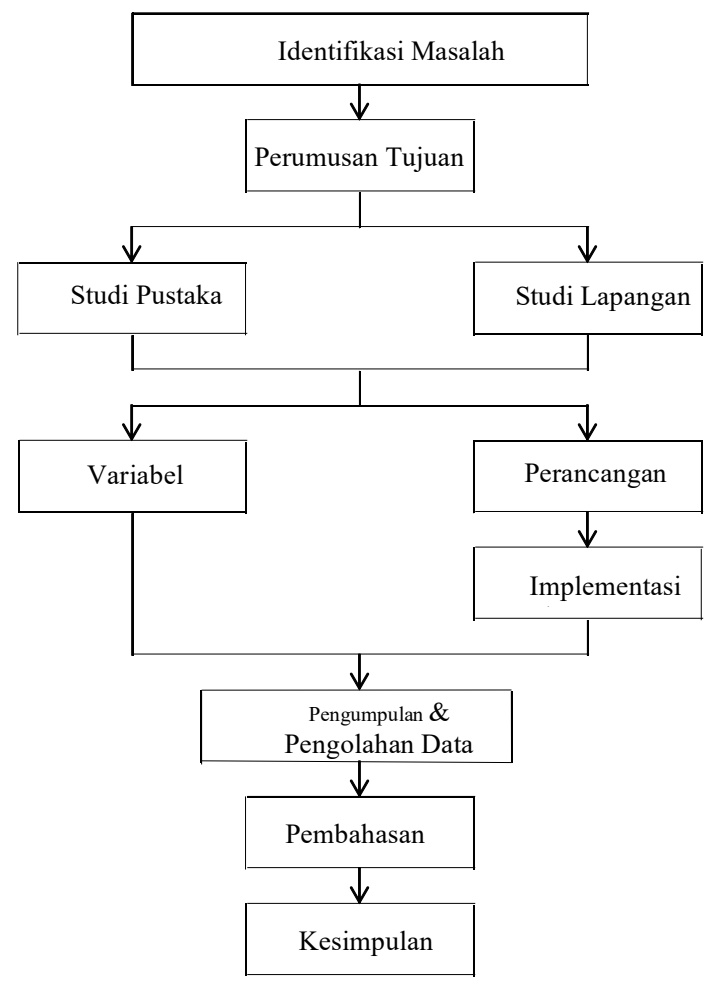

G

Gambar 4. Kerangka kerja penelitian

\section{Identifikasi Masalah}

Pada tahap ini, mengidentifikasi permasalahan yang muncul ditempuh dengan cara melakukan survei secara langsung di taman kanak-kanak. Penelitian dilakukan dengan cara obsevasi dan intervidu pemilik taman kanak-kanak. Hasil obervasi dan interview menghasilkan suatu rencana penggunaan mobile robot sebagai media bermain untuk menganalisa kognitif.

\section{Perumusan Tujuan}

Perumusan masalah menjadi langkah selanjutnya setelah topik riset ditentukan. Pada penelitian ini perumusan masalah yang dihasilkan adalah efektifitas penggunaan mobile robot dapat meningkatkan kognitif dan menganalisa sebelum dan sesudah dari hasil pengolahan data dengan uji Wilcoxon. 


\section{Studi Pustaka}

Studi pustaka dilakukan untuk mendapatkan referensi mengenai teori-toeri dan metode yang mendukung penelitian. Langkah ini dilakukan dengan cara mencari referensi dari beberapa buku, jurnal, handbook, atau artikel mengenai kognitif anak serta teori-teori yang terkait dengan materi penelitian.

\section{Studi Lapangan}

Studi lapangan dilakukan di taman kanak-kanak.

\section{Identifikasi Variabel}

Variabel yang digunakan dalam penelitian dapat diklafikasi menjadi variabel indenpenden dan variabel dependen

\section{Variabel Independen}

Merupakan variabel bebas dimana dalam penelitian ini ialah variabel kognitif, yang dalam penelitian ini adalah perlakuan dari mobile robot.

\section{Variabel Dependen}

Variabel ini bersifat terikat, yaitu kemampuan motorik halus meliputi dimensi sebagai berikut : gerak mata, gerak tangan, komunikasi, kognitif.

\section{Desain Rancangan}

Pada tahap desain, peneliti membuat alur kerja sistem yang telah didapat dari analisis pengumpulan kebutuhan. Kemudian pengumpulan peralatan dan bahan-bahan untuk membuat perangkat.

\section{Sensor}

Sensor yang berfungsi sebagai pembaca bagaimana tingkat pemantulan permukaan lantai yang diberi garis sebagai track dan tidak. Karena prinsip dari sensor yang digunakan adalah pemantulan dari pemancar ke penerima, jika penerima yang menggunakan photodiode mendapatkan pancaran yang besar, maka resistansi dari photodiode tersebut menjadi kecil, begitu juga sebaliknya. Setelah bagaimana kondisi permukaan yang dibaca oleh sensor, maka perbedaan tadi dikirim ke mikrokontroler untuk diproses.

\section{Button}

Button berfungsi sebagai pengatur agar Line Follower bertugas sesuai kemauan kita yang akan diproses mikrokontroler dengan data-data lainnya.

\section{Mikrokontroler ATMega32}

Mikrokontroler yang berjenis AVR seri ATMega32 sebagai otak dari Line Follower yang bertugas memproses data inputan dan mengeluarkan data yang telah diproses ke LCD dan Driver Motor

\section{Driver Motor}

Sebagai penguat dari output mikrokontroler dan mengendalikan motor agar bisa bergerak maju dan mundur

\section{LCD}

Sebagai pemroses data dari mikrokontroler menjadi tulisan agar mempermudah user dalam pembacaan input, eksekusi program dan output.

\section{Pengujian Sistem}

Pada tahap ini dilakukan uji coba program untuk memastikan program bebas dari kesalahan-kesalahan, setelah itu alat dicoba dan dites proses kerjanya. Pengujian ini meliputi beberapa tahap, yaitu:

1. Pengujian perangkat keras (Hardware).

Pengujian hardware bertujuan untuk memastikan tidak ada kesalahan dalam rangkaian elektronik.

2. Pengujian perangkat lunak (Software). 
Pengujian ini dilakukan dengan melakukan pengujian terhadap program dengan cara memberi masukan dan mengamati keluarannya.

\section{Pengumpulan dan Pengolahan Data Pengumpulan Data}

Metode pengumpulan data dalam riset pasar ini dilakukan dengan cara menyebarkan kuesioner yang diisi oleh pembimbing atau guru penelitian ini dilakukan untuk mencari perbedaan hasil penelitian dengan cara memberikan pretest (pengamatan awal) terhadap tingkat kognitif selanjutnya dilakukan posttest (pengamatan terakhir) terhadap peningkatan kognitif setelah dilakukan mobile robot.

\section{Pengolahan Data}

Pengolahan data menjadi tahap
selanjutnya setelah data-data yang
dibutuhkan terkumpul. Statistik $\mathrm{Uji}$
Wilcoxon digunakan sebagai alat untuk
mengolah data-data tersebut.

\section{Analisa Pembahasan}

Analisis pembahasan menggunakan analisis uji Wilcoxon untuk mencari perbedaan hasil penelitian dengan cara memberikan pretest (pengamatan awal) terhadap tingkat kognitif sebelum melakukan terapi selanjutnya dilakukan posttest (pengamatan terakhir) terhadap peningkatan kognitif setelah dilakukan terapi bermain mobile robot. Dalam analisis ini dapat memeriksa apakah penelitian yang dibuat pada tahap sebelumnya telah valid, jika penelitan belum valid maka perlu dilakukan pengumpulan ulang data dan analisis data.

\section{Kesimpulan}

Hasil akhir dari penelitian ini adalah penarikan kesimpulan berupa hasil analisis data dan strategi peningkatan media bermain untuk meningkatkan kognitif

\section{HASIL}

\section{Blok Diagram Dan Cara Kerja}

Untuk lebih memudahkan proses perancangan dan cara kerja masing-masing rangkaian maka akan dibuat suatu diagram blok terlebih dahulu. Hal ini sangat penting, karena dalam pembuatan suatu alat setiap rangkaian saling berhubungan dan mempengaruhi kinerja alat lainnya. Sehingga hasil yang didapat sesuai dengan keinginan dan teori yang berlaku.

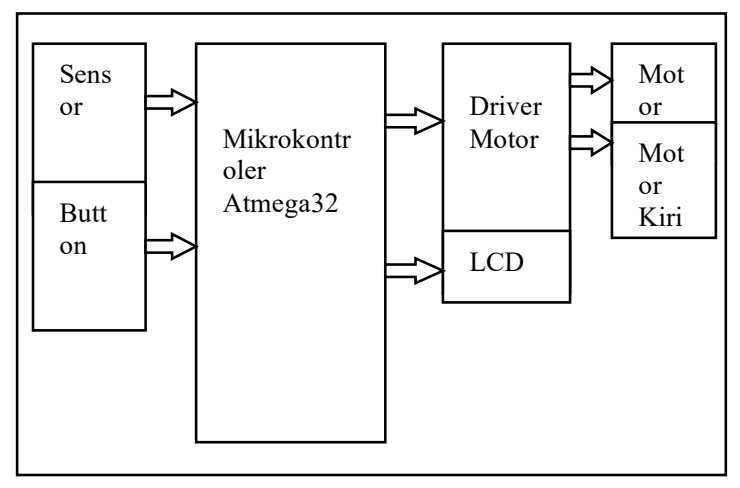

Gambar 6. Blok Diagram Dan Cara Kerja

\section{Alur Kerja Sistem}

Cara kerja dari sistem robot line follower ialah dimulai dari pembacaan lintasan oleh sensor photodiode berserta LED superbright yang mana intensitas pantulan sinar LED superbright akan berbeda jika terkena bidang pantul yang gelap dengan bidang pantul yang lebih terang. Dari perbedaan inilah dimanfaatkan sebagai pendeteksi lintasan dan selanjutnya diteruskan pada rangkaian pengkondisi sinyal (komparator). Rangkaian komparator LM324 berfungsi untuk membandingkan nilai yang dibaca sensor photodiode dengan 
nilai referensi komparator sehingga perbedaan terlihat saat sensor photodiode mendeteksi objek pantul gelap maupun terang. Hasil keluaran komparator kemudian diteruskan ke portA rangkaian sistem minimum mikrokontroller ATmega16 untuk diproses. Semua kondisi yang dibaca oleh sensor akan diproses oleh mkrokontroller ATmega16. Setelah kondisi logika diproses oleh mikrokontroller maka output akan di teruskan ke rangkaian driver melalui portD. Kondisi logika output mikrokontroller tersebut digunakan untuk menggerakan motor robot.

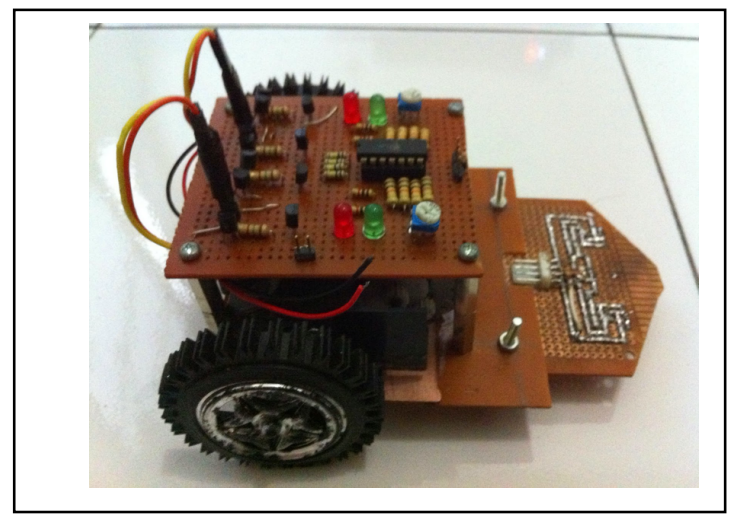

Gambar 7. Mobile Robot

1) Robot line follower ini akan bekerja apabila sensor membaca jalur yang berwarna hitam

2) Output komparator akan belogika high apabila tegangan referensi lebih besar dari tegangan input komparator dan berlogika low apabila tegangan referensi lebih kecil dari tegangan input komparator.

3) Rangkaian sistem minimum mikrokontroller ATmega16 akan bekerja apabila diberikan tegangan sumber sebesar 5 volt

4) Rangkaian driver akan bekerja dan menggerakkan motor apabila diberikan input belogika high dan kaki enable IC L293D diberikan logika high.

\section{Penyajian Data Hasil Peneliti}

Penyajian data dengan tekstular/naratif, tabel untuk melihat perkembangan kognitif anak sebelum dan setelah diberi bermain mobile robot.

Hubungan Timbal Balik Anak Autis sebelum dan setelah Dilakukan Pendekatan Bermain

Sebelum dan setelah dilakukanpendekatan bermain, sub aspek interaksi social berupa hubungan timbale balik dapat dilihat dalam tabel berikut :

Tabel 1. Distribusi frekuensi Hubungan Timbal Balik kognitif yang Menjadi Responden Penelitian

Tabel 1. Distribusi frekuensi

\begin{tabular}{llll}
\hline \multirow{2}{*}{ No } & Kriteria & \multicolumn{2}{c}{ Persentase(\%) } \\
\cline { 3 - 4 } & & Sebelum & $\begin{array}{l}\text { Sesuda } \\
\text { h }\end{array}$ \\
\hline 1. & Baik & 45 & 65 \\
\hline 2. & Cukup & 35 & 25 \\
\hline 3. & Kurang & 20 & 10 \\
\hline \multicolumn{2}{l}{ Total } & $\mathbf{1 0 0}$ & $\mathbf{1 0 0}$ \\
\hline
\end{tabular}

\section{KESIMPULAN}

Adapun disimpulkan sebagai berikut :

1. Penggunaan Mobile robot dapat meningkatkan kognitif anak.

2. Penggunaan robot juga dapat mencegah terjadi kelainan dari anak seperti autis dan lain sebagainya.

3. Pengujian dapat dianalisa dengan menggunakan Rank Wilcoxon.

\section{DAFTAR PUSTAKA}

[1]. Bourane, S., Grossmann, K. S., Koch, 
S., Goulding, M., Bourane, S., Grossmann, K. S., ... Stam, F. J. (2015). Identification of a Spinal Circuit for Light Touch and Fine Motor Control Article Identification of a Spinal Circuit for Light Touch and Fine Motor Control. Cell, 160(3), 503-515.

https://doi.org/10.1016/j.cell.2015.01. 011

[2]. Corsi, C., Martins, M., Andrade, L. De, \& Marques, P. (2016). Impact of extrinsic factors on fine motor performance of children attending day care. Revista Paulista de Pediatria (English Edition), 34(4), 439-446.

https://doi.org/10.1016/j.rppede.2016. 03.007

[3]. Gumus, O., Topaloglu, M., \& Ozcelik, D. (2016). The Use of Computer Controlled Line Follower Robots in Public Transport. Procedia Computer Science, 102(August), 202-208.

https://doi.org/10.1016/j.procs.2016.0 9.390

[4]. Larkin, E., Ivutin, A., Kotov, V., \& Yesikov, D. (2017). Generalized model of cyclic dispatching discipline in mobile robots based on swarm systems. Procedia - Procedia Computer Science, 103(October 2016), 454-458. https://doi.org/10.1016/j.procs.2017.0 1.019

[5]. Marx, A., Backes, C., Meese, E., Lenhof, H., \& Keller, A. (2016). EDISON-WMW : Exact Dynamic Programing Solution of the Wilcoxon - Mann - Whitney Test, 14, 55-61. https://doi.org/10.1016/j.gpb.2015.11. 004
[6]. https://doi.org/10.1016/j.procs.2014.1 1.054

[7]. Wilson, N., Faisal, T., Al-assadi, H. M. A. A., \& Iwan, M. (2012). Pick and Place ABB Working with a Liner Follower Robot. Procedia - Procedia Computer Science, 41(Iris), 13361342.

https://doi.org/10.1016/j.proeng.2012. 07.319 